\title{
COMPARISON OF THE EFFECTS OF CYPROTERONE, CYPROTERONE ACETATE AND OESTRADIOL ON TESTICULAR FUNCTION, ACCESSORY SEXUAL GLANDS AND FERTILITY IN A LONG-TERM STUDY ON RATS
}

\author{
H. STEINBECK, M. MEHRING AND F. NEUMANN \\ Experimental Research Pharma, Schering $A G$, \\ Department of Endocrinology, 1 Berlin 65
}

(Received 15th August 1970)

\begin{abstract}
Summary. Treatment of adult male rats with oestradiol, cyproterone acetate or cyproterone affected spermatogenesis, accessory sexual glands and fertility in different ways. Suppression of Leydig cells, spermatogenesis, accessory sexual glands and fertility ran parallel in oestradiol-treated animals. High doses of cyproterone acetate caused severe suppression of the accessory sexual glands and fertility but had only a slight inhibitory influ. ence on spermatogenesis, Leydig cells were only temporarily affected. With high doses of cyproterone, Leydig cells were over-stimulated initially but returned to normal appearance during treatment. There was almost no effect on spermatogenesis but the accessory sexual gland weights and fertility were markedly reduced. Recovery from any changes was rapid after cessation of cyproterone acetate and cyproterone treatment but not after oestradiol.

Lower doses of cyproterone acetate and cyproterone did not affect testicular morphology but significantly depressed the accessory sexual gland weights. Different mechanisms of action for the three steroids are discussed. Objections are raised against the use of cyproterone acetate for the control of male fertility.
\end{abstract}

\section{INTRODUCTION}

Accessory sexual gland function as well as sexual behaviour are among the processes that are maintained by the action of testicular androgens in male mammals including man. Prevention of access by androgens to these targets, either surgically or chemically, results in impairment or even abolition of their normal function.

Cyproterone or its acetate has been claimed to inhibit any effects of endogenous or exogenous androgens (Neumann, von Berswordt-Wallrabe, Elger, Steinbeck, Hahn \& Kramer, 1970), presumably in the main by competitive antagonism. Differences in the actions of these steroids on different androgen-dependent targets may be due to species differences. Inhibition of libido in sexually 
naive rats (Steinbeck, Elger \& Neumann, 1967) as well as complete lack of influence in sexually experienced rats and guinea-pigs (Zucker, 1966; Beach \& Westbrook, 1968; Whalen \& Edwards, 1969; Whalen \& Luttge, 1969) or even stimulatory effects (Davidson \& Bloch, 1969) of cyproterone and cyproterone acetate have been reported. On the other hand, depression of libido by cyproterone acetate treatment was found almost invariably in men, particularly in cases of aberrant sexuality (Laschet \& Laschet, 1967a, b; Laschet, Laschet, Fetzner, Glaesel, Mall \& Naab, 1967; Giese, Krause \& Schmidt, 1968; Hoffet, 1968; Ott, 1968; Seebandt, 1968).

There is more agreement concerning the inhibitory effects of cyproterone and cyproterone acetate on the accessory sexual glands and spermatogenesis. Qualitative species differences have not so far been found. Treatment of aberrant sexuality in men with antiandrogens is likely, therefore, to interfere with accessory sexual gland function and spermatogenesis, depending on the dosage.

It is known from short-term treatment studies on rats that higher doses are required to arrest spermatogenesis than to depress the accessory sexual glands (Junkmann \& Neumann, 1964 ; Neumann, Elger, Steinbeck \& von BerswordtWallrabe, 1968; Neumann, Steinbeck, Elger \& von Berswordt-Wallrabe, 1968). During long-term treatment, however, changes in gonadotrophinstimulated testosterone secretion rates and therefore an altered androgen/antiandrogen ratio might occur. It is known that hypothalamic centres controlling gonadotrophin secretion change their sensitivity in response to long-term gonadal steroid deprivation or excess (Hohlweg, 1956).

The present study was designed: (1) to compare the effects on testicular function and accessory sexual glands during and after long-term treatment with antiandrogens possessing different properties, (2) to attempt to find an antiandrogen dose which does suppress the accessory sexual glands but does not affect spermatogenesis, and (3) to elucidate the different mechanisms of action of antiandrogens and a gonadotrophin inhibitor by comparison of their effects on testicular function and accessory sexual glands.

It seemed particularly desirable to investigate the influence of cyproterone acetate on reproductive functions since it is planned to bring this compound to the market for treatment of aberrant sexuality in men.

\section{MATERIALS AND METHODS}

In the first experiment, three groups of male Sprague-Dawley rats with an initial body weight of $200 \mathrm{~g}$ were injected subcutaneously with daily doses of either $10.0 \mathrm{mg}$ cyproterone acetate/animal (seventy-one animals) or $1.0 \mathrm{mg}$ oestradiol/animal (seventy animals) or fed $40.0 \mathrm{mg}$ cyproterone/animal (sixtyfive animals) by stomach tube daily. The cyproterone and cyproterone acetate were synthesized by Dr R. Wiechert of Schering AG, Berlin, West Germany. Cyproterone acetate and oestradiol were dissolved in a mixture of benzyl benzoate and castor oil $(1: 10)$, cyproterone was suspended in carboxymethylcellulose/water $(1: 50)$. Daily doses were contained in $0.2 \mathrm{ml}$ of the solvent or $0.5 \mathrm{ml}$ of the suspension fluid. 
All animals were treated over a period of 9 weeks. Every 3 weeks, seven or eight animals per treatment group were killed, the first group 3 weeks after the initiation of treatment, the last groups (these groups consisting of fourteen or fifteen animals) 24 weeks after the beginning of the experiment, i.e. after a recovery period of 15 weeks. The night before autopsy, each male was placed with two pro-oestrous females. Fertility was checked by the presence of

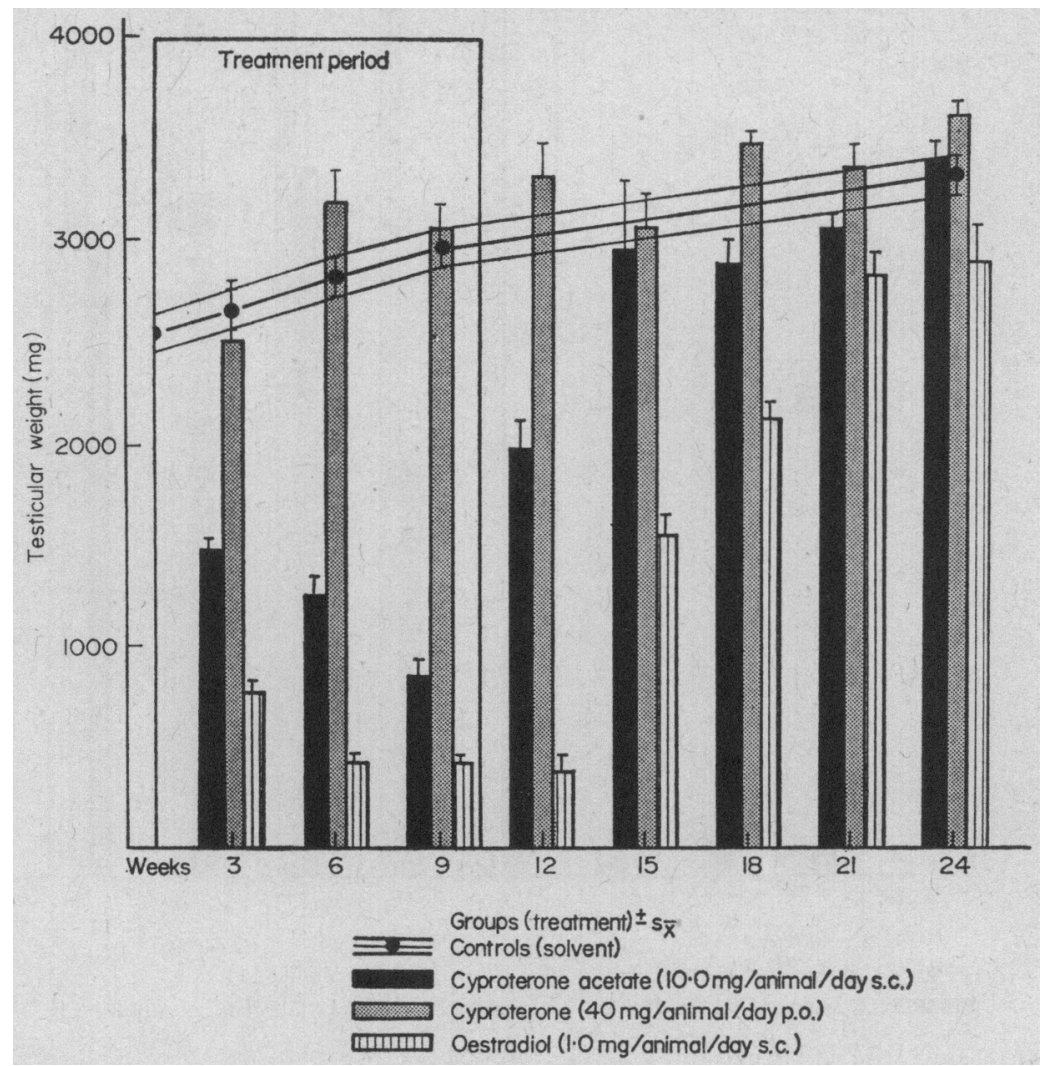

TEXT-FIG. 1. Testicular weights of mature rats during and after high dose treatment with cyproterone acetate, cyproterone or oestradiol.

implantation sites after 8 days. At autopsy, the prostates, seminal vesicles, levator ani muscles, testes and pituitaries were removed and weighed. The testes were fixed in Bouin's solution and further processed by the haematoxylin-eosin staining technique for histological examination.

In the second experiment, the same regimen of treatment, fertility tests and autopsy was applied, except that the doses of cyproterone acetate were 2.5 $\mathrm{mg} /$ animal (sixty animals), while those of cyproterone were $10.0 \mathrm{mg} / \mathrm{animal}$ (thirty-four animals) and of oestradiol, $0.25 \mathrm{mg} /$ animal (sixty animals). The treatment period lasted for 6 weeks and the recovery period for 12 weeks.

\section{RESULTS}

The differences in the results of treatment with cyproterone, its acetate and 


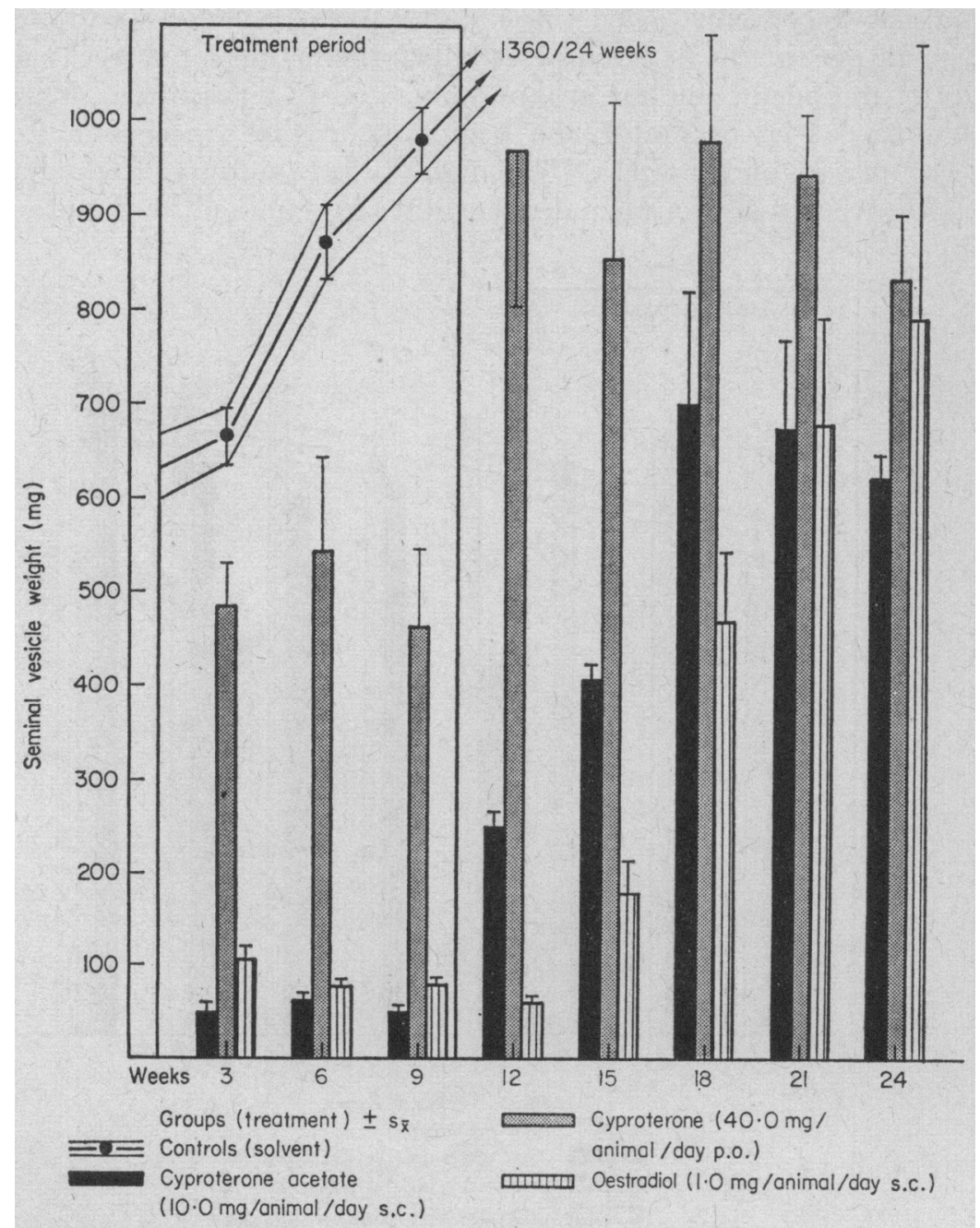

TExT-Fic. 2. Seminal vesicle weights of mature rats during and after high dose treatment with cyproterone acetate, cyproterone or oestradiol.

\section{EXPLANATION OF PLATE 1}

(a) and (b): Cyproterone-treated group ( $40.0 \mathrm{mg} / \mathrm{animal} /$ day orally for 9 weeks). Under cyproterone influence, marked overstimulation of the Leydig cells was found after 3 weeks of treatment (a) concomitantly with impairment of spermiogenesis. After 6 weeks or 9 weeks of treatment, however, the testicular morphology was completely normal (b). No changes in tubular diameters were seen.

(c) and (d): Oestradiol-treated group ( $1.0 \mathrm{mg} /$ animal/day subcutaneously for 9 weeks) Maximal suppression of the Leydig cells associated with an arrest of spermatogenesis was already seen after 3 weeks of oestradiol treatment. The small tubules contained heavily depopulated germinal epithelium and necroses were also found in a great number of tubules. The most advanced stages of spermatogenesis were primary spermatocytes. This picture was found throughout the treatment period and even 3 weeks after cessation of treatment (c). After a recovery period of 6 weeks (d), spermatids were seen. Spermiogenesis was not completely restored until 15 weeks after cessation of treatment. 


\section{PLATE 1}
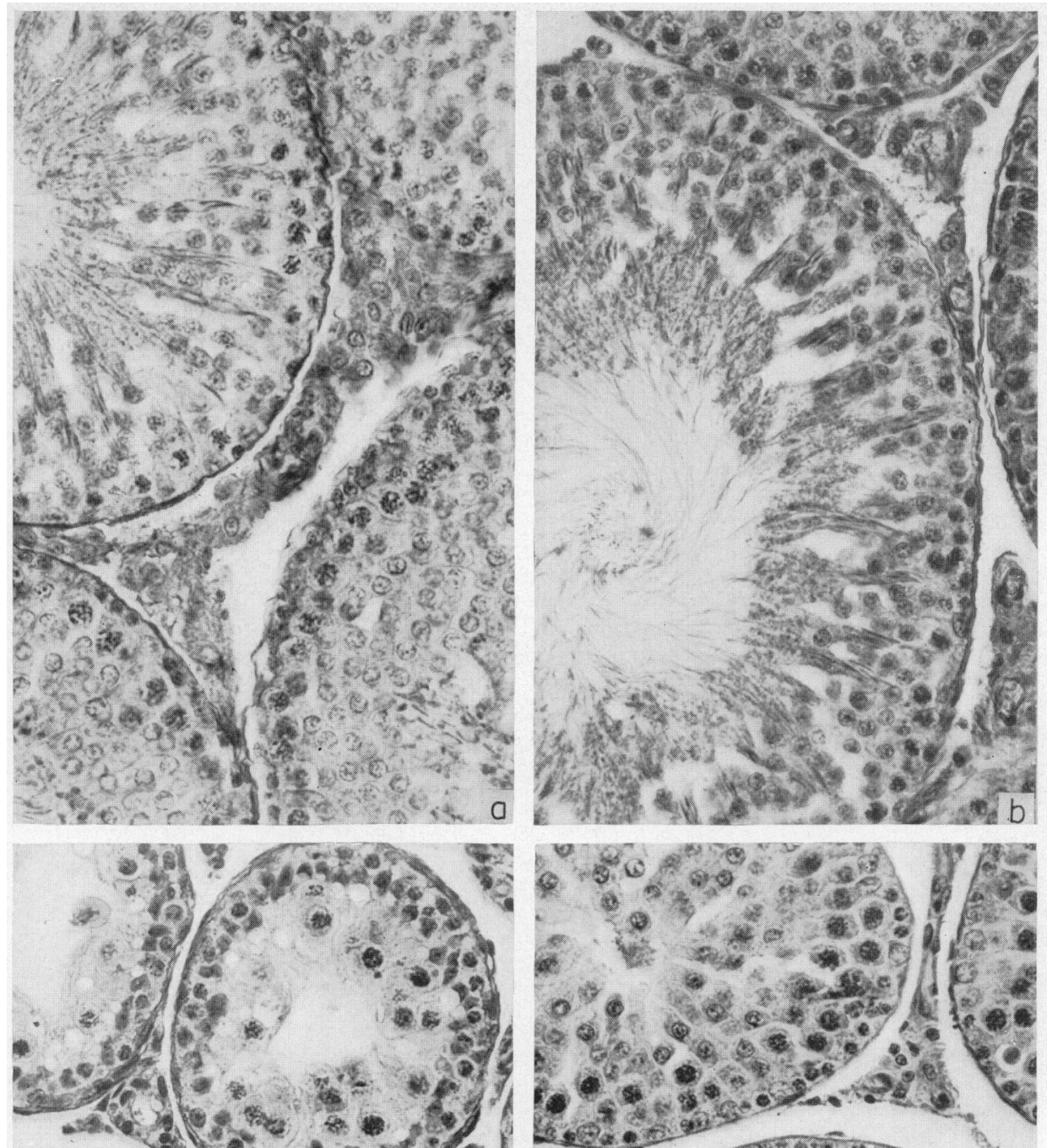

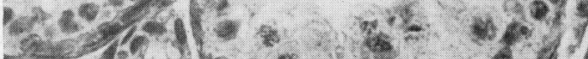
$-2 \mathrm{~s}=0$
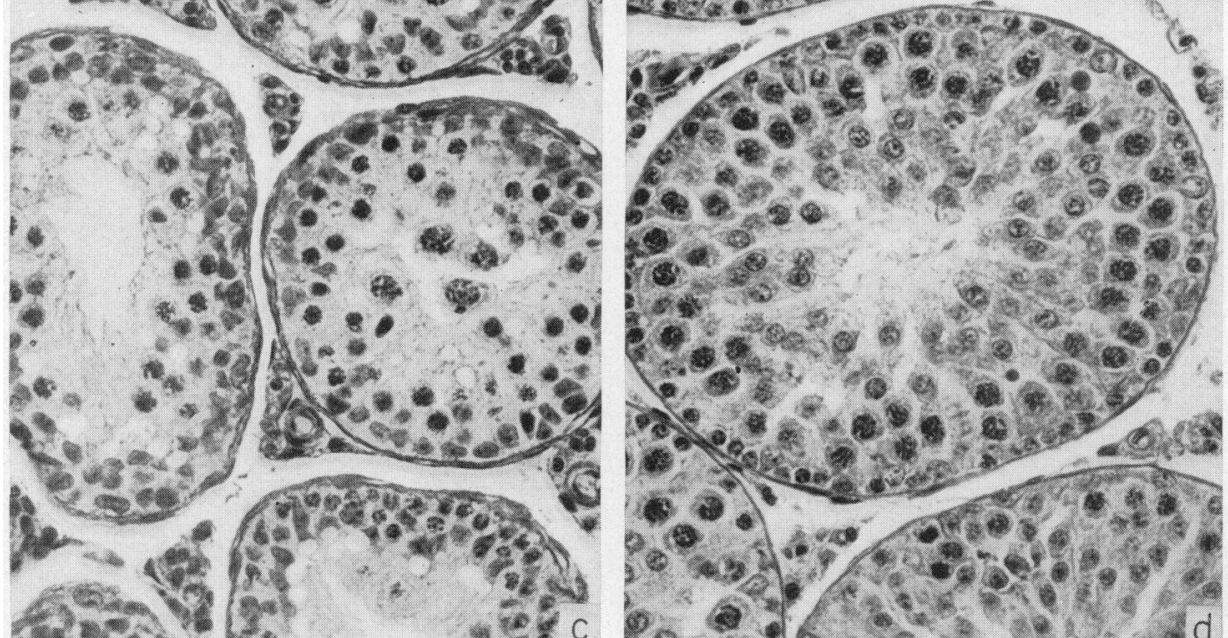

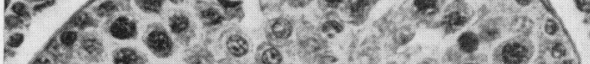

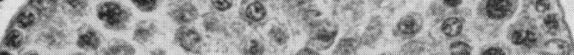

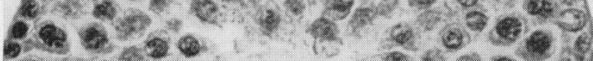

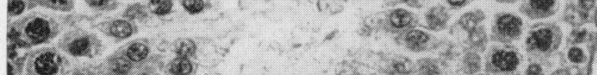

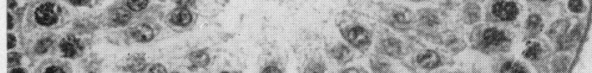

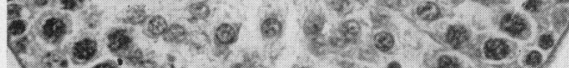

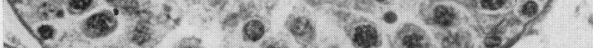

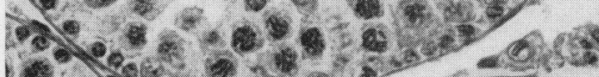

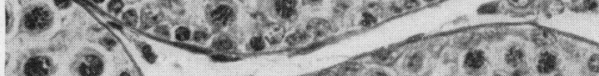

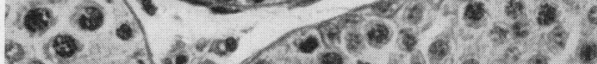
10 abs

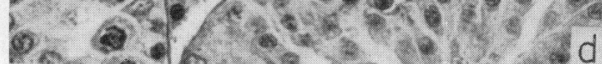

(Facing p. 68) 
PLATE 2
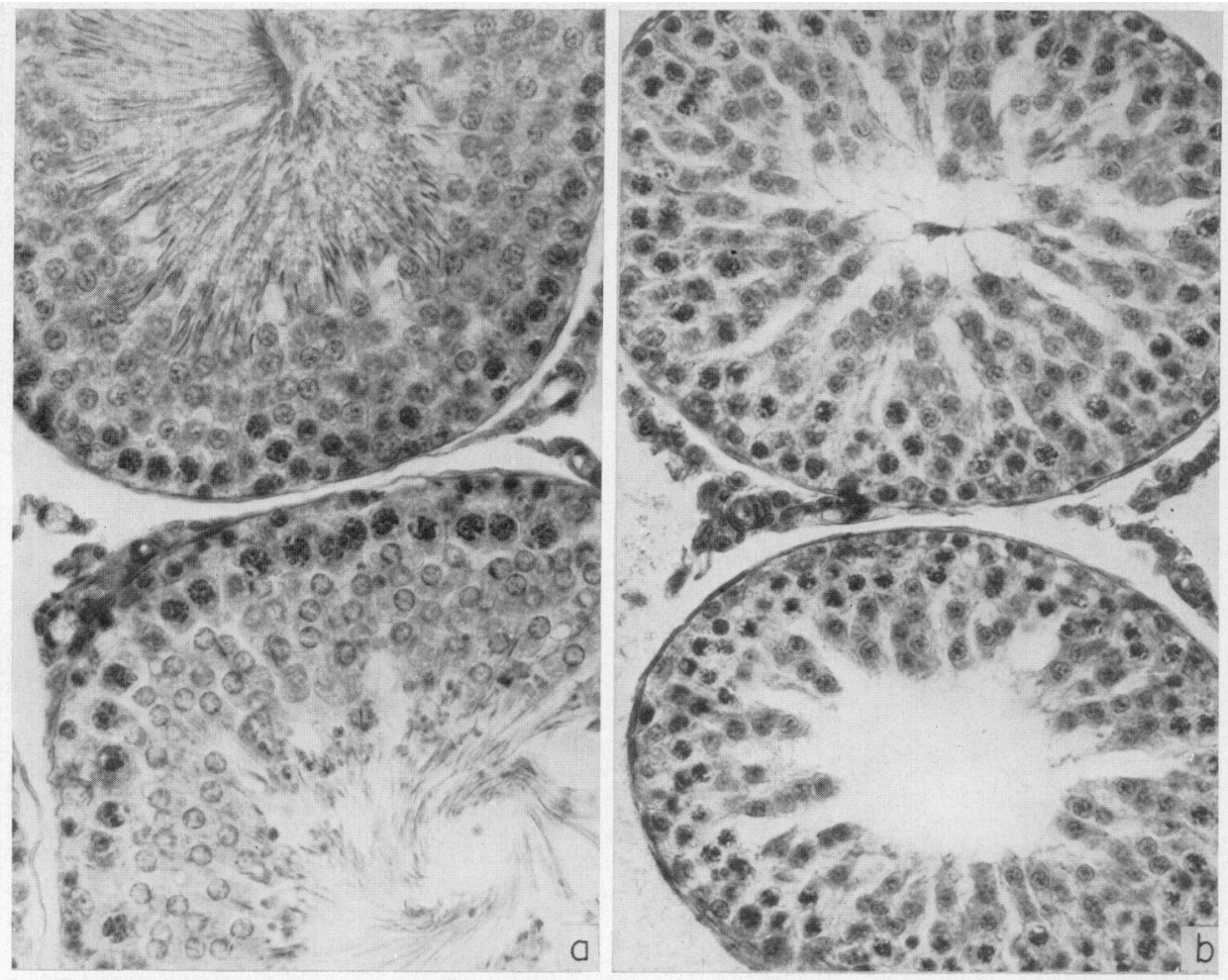

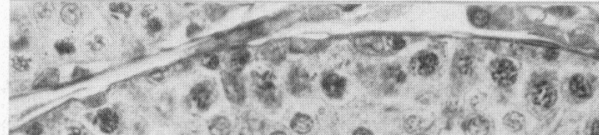

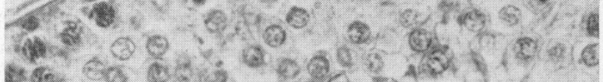

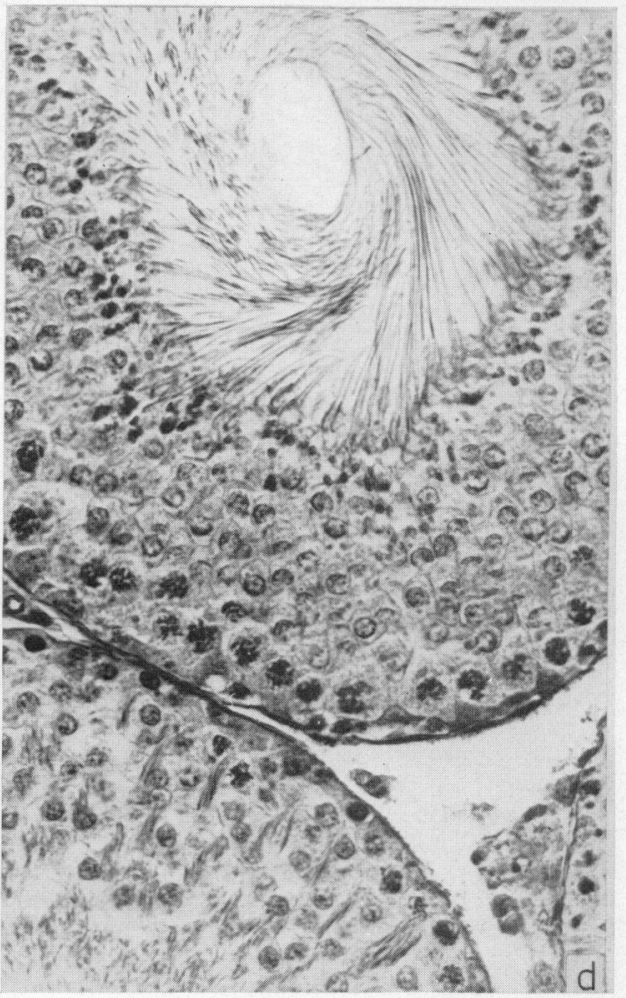

(Facing p. 69) 
oestradiol indicate differences in the mechanism of action of these three compounds on the reproductive system.

In the case of oestradiol, testicular depression and atrophy of the accessory sexual glands ran parallel (Text-figs. 1 to 6 ). Leydig cell atrophy was already complete by the 3 rd week of treatment, at which time spermatogenesis and accessory sexual glands were not yet maximally suppressed. Inversely, Leydig cells were the first components of the testis to be restored after cessation of treat-

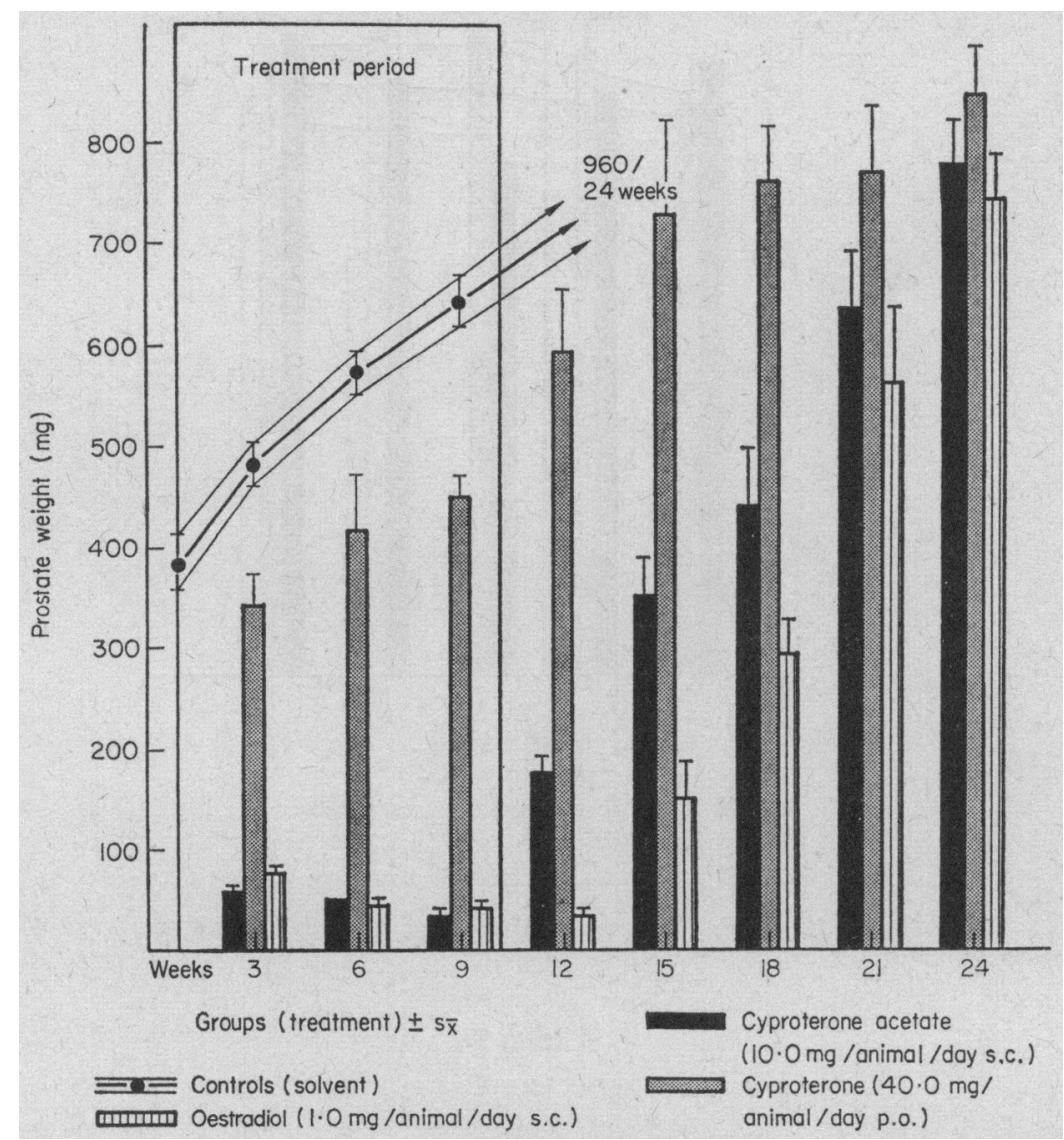

Text-Fig. 3. Prostate weights of mature rats during and after high dose treatment with cyproterone acetate, cyproterone or oestradiol.

\section{EXPLANATION OF PLATE 2}

(a): Normal control. (b), (c) and (d): Cyproterone-acetate-treated group (10.0 mg/ animal/ day subcutaneously for 9 weeks). With increasing duration of cyproterone acetate treatment, gradual regression of spermatogenesis and tubular diameters took place. Spermatids represented the most advanced stage of spermatogenesis after 9 weeks (b). Three weeks after cessation of treatment (c), spermatogenesis was normal again although the cell count of the germinal epithelium was still reduced. Six weeks after cessation of treatment (d), testicular morphology was completely normal except that the tubular diameters were above the normal range. There were no changes in Leydig cell structure except a very slight depression after 6 weeks of treatment and some hypertrophy 3 weeks after the cessation of treatment. 
ment, followed later by the recovery of the accessory sexual glands. Recovery of normal fertility and spermatogenesis was not even complete 15 weeks after the cessation of treatment (Table 1 , Plate 1 ). The effects of 0.25 and $1.0 \mathrm{mg}$ oestra-

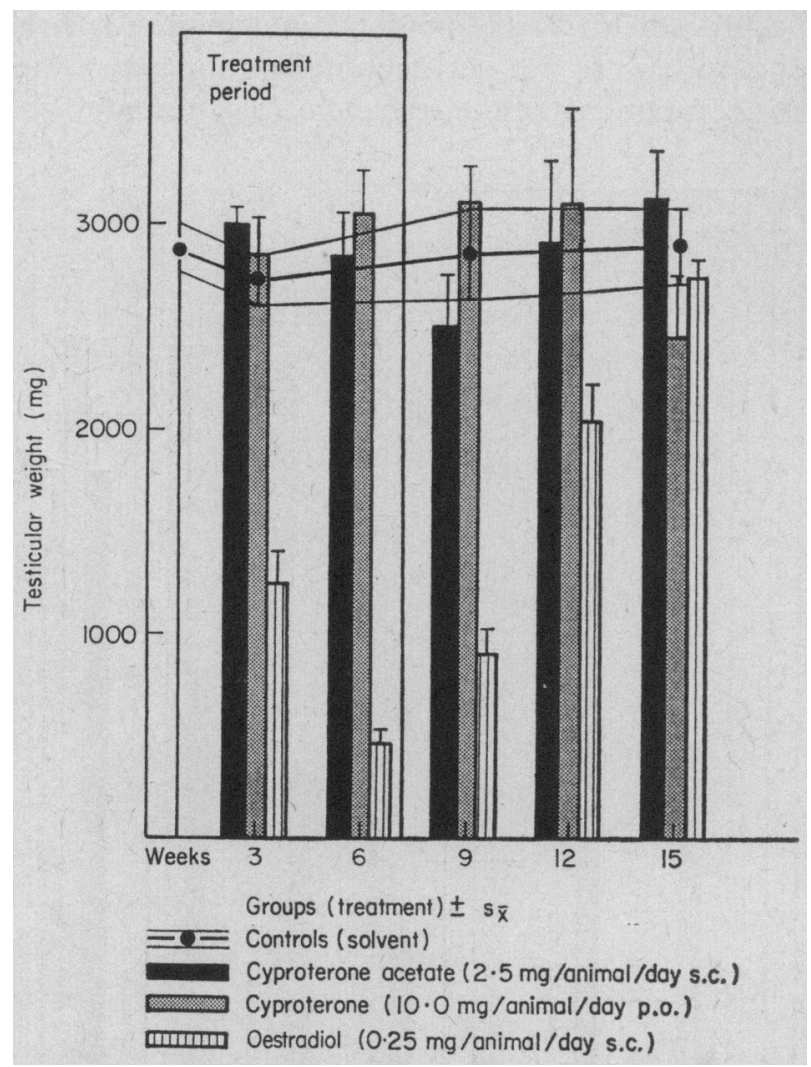

TexT-Fig. 4. Testicular weights of mature rats during and after low dose treatment with cyproterone acetate, cyproterone or oestradiol.

TABLE 1

FERTILITY RATES AS MEASURED BY THE ABILITY TO IMPREGNATE FEMALES

\begin{tabular}{c|c|c|c}
\hline Weeks & $\begin{array}{c}\text { Cyproterone acetate } \\
(10.0 \mathrm{mg} / \text { animall } \\
\text { day s.c.) }\end{array}$ & $\begin{array}{c}\text { Cyproterone } \\
\left(\begin{array}{c}40.0 \mathrm{mg} / \text { animal } \\
\text { day p.o. })\end{array}\right.\end{array}$ & $\begin{array}{c}\text { Oestradiol } \\
(1.0 \mathrm{mg} / \text { animal } \\
\text { day s.c. })\end{array}$ \\
\hline 3 & $0 \%(0 / 8)$ & $50 \%(4 / 8)$ & $0 \%(0 / 8)$ \\
6 & $0 \%(0 / 8)$ & $38 \%(3 / 8)$ & $0 \%(0 / 8)$ \\
9 & $0 \%(0 / 8)$ & $57 \%(4 / 7)$ & $0 \%(0 / 8)$ \\
\hline 12 & $38 \%(3 / 8)$ & $71 \%(5 / 7)$ & $0 \%(0 / 8)$ \\
15 & $88 \%(7 / 8)$ & $57 \%(4 / 7)$ & $0 \%(0 / 8)$ \\
18 & $50 \%(4 / 8)$ & $57 \%(4 / 7)$ & $0 \%(0 / 8)$ \\
21 & $75 \%(6 / 8)$ & $71 \% \%(5 / 7)$ & $75 \%(6 / 8)$ \\
24 & $100 \%(15 / 15)$ & $93 \%(13 / 14)$ & $64 \%(9 / 14)$ \\
\hline
\end{tabular}

s.c., subcutaneously; p.o., orally. 
diol did not differ in any respect, presumably because $0.25 \mathrm{mg}$ is already a supramaximal dose.

The effects of the high dose of cyproterone acetate $(10.0 \mathrm{mg})$ were less severe. Besides complete inhibition of fertility and suppression of accessory sexual gland growth, there was only a mild inhibition of spermatogenic activity along with

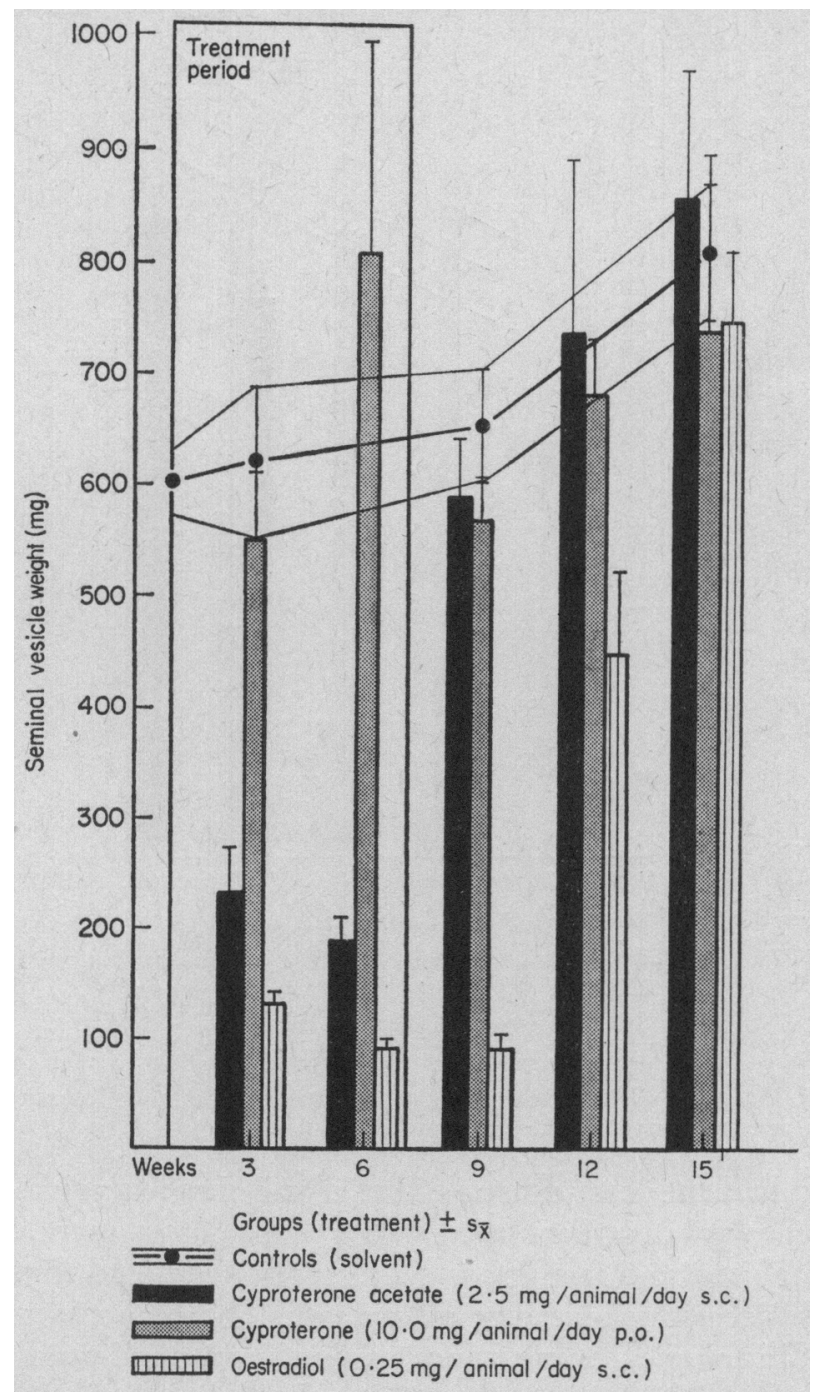

TEXT-FiG. 5. Seminal vesicle weights of mature rats during and after low dose treatment with cyproterone acetate, cyproterone or oestradiol.

some involution of the Leydig cells for the first 6 weeks of treatment, followed by normal appearance of the interstitium and marked inhibition of spermatogenesis by the end of the treatment period. Recovery of these functions was more rapid than with oestradiol, and there was evidence of some Leydig cell hypertrophy 3 weeks after the cessation of treatment (Plate 2). 
When the low dose $(2.5 \mathrm{mg} /$ animal/day) was administered, no changes in testicular weight or morphology were found, but there was a marked suppression of the prostate and seminal vesicle weights. Three weeks after cessation of treatment, seminal vesicle weights were completely restored and the prostate weights were near those of the untreated controls (Text-figs. 4 to 6 ).

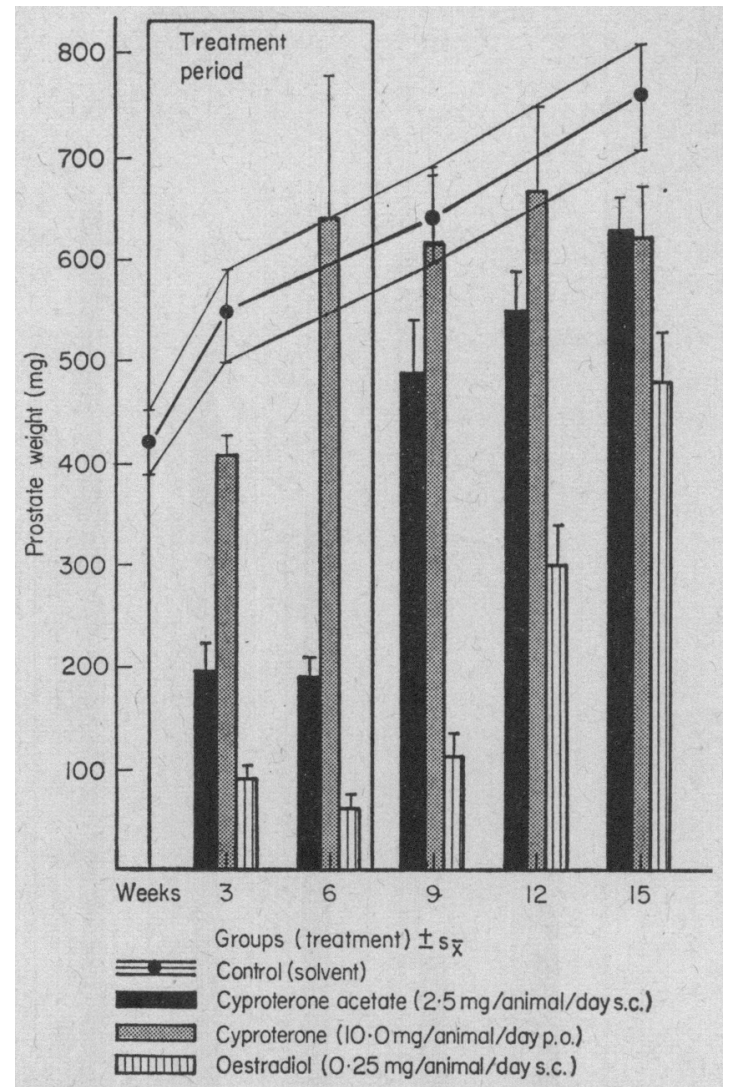

Text-Fig. 6. Prostate weights of mature rats during and after low dose treatment with cyproterone acetate, cyproterone or oestradiol.

Gyproterone had the least drastic effect of the three steroids. With the high dose, Leydig cells were overstimulated after 3 weeks of treatment. Spermiogenesis was slightly inhibited and fertility was markedly decreased together with suppression of the accessory sexual gland weights. With increasing duration of treatment, the histological appearance of the Leydig cells and spermiogenesis returned to normal while the accessory sexual glands, particularly the seminal vesicles, remained inhibited to a moderate extent, rapidly returning to normal after cessation of treatment (Plate 1).

At the low dose of cyproterone $(10.0 \mathrm{mg} /$ animal $)$, testicular weight and morphology remained completely normal and there were no changes in the seminal vesicle weight. The prostate weight was slightly but significantly decreased after 3 weeks. At the end of the treatment period, however, it was within control range. 


\section{DISCUSSION}

A comparison of the effects of the three steroids both on the testis and on the accessory sexual glands indicates three different mechanisms of action.

The effects of oestradiol can be explained as resulting from marked feedback suppression of gonadotrophin secretion resulting in inhibition of the interstitial tissue of the testes and secondarily in depression of the accessory sexual glands and spermatogenesis. Consequently, Leydig cells are the first structures to be restored after cessation of treatment, to be followed later by the recovery of the accessory sexual glands which depend on androgenic rather than on gonadotrophic stimulation.

Cyproterone, on the contrary, has no inhibitory effect on the Leydig cells. Particularly with the high dose, the interstitium was over-stimulated after 3 weeks of treatment whereas spermiogenesis and, to an even greater extent, the accessory sexual glands, were distinctly inhibited at this time. These effects can be explained by the local antagonism of cyproterone and endogenous androgens. Since this compound also acts as an antiandrogen on the feedback receptors in the hypothalamus (Neumann, 1966; Neumann, Elger \& von Berswordt-Wallrabe, 1966; Neumann, Elger, von Berswordt-Wallrabe \& Kramer, 1966; Bloch \& Davidson, 1967; von Berswordt-Wallrabe \& Neumann, $1967,1968)$, there is a concomitant increase in gonadotrophin secretion which is reflected here in an initial hypertrophy of the Leydig cells. In consequence, androgen synthesis by the Leydig cells should also have been increased. Enhanced androgen levels have indeed been observed after cyproterone treatment in men (Voigt, Apostolakis \& Klosterhalfen, 1968).

It is, however, difficult to explain why spermiogenesis was decreased when the Leydig cells were over-stimulated after 3 weeks of treatment and returned to normal by 6 weeks when the interstitium no longer showed signs of hypertrophy. Differing latencies in the response of spermatogenesis and interstitial tissue to changes in the hormonal environment might be involved.

The return of the appearance of the interstitial tissue to normal can be explained by the assumption that gradually increasing circulating levels of testosterone resulting from increased gonadotrophin secretion finally overcame part of the antagonism on the feedback receptors with an eventual partial reversal of the increased gonadotrophin secretion. As a result, Leydig cell hypertrophy ceased to be manifested.

Since these experiments were terminated, similar conclusions have also been stated by other authors in two recent publications (Mietkiewski \& Lukaszyk, 1969; Mietkiewski, Malendowicz \& Lukaszyk, 1969), although no data on accessory sexual glands were reported. In their studies, only $10.0 \mathrm{mg}$ cyproterone/animal/day were administered, a dose that had no effect on the testis in our experiments. This discrepancy could be due to strain differences and possibly also to differences in body weight which were not reported.

The distinct inhibition of spermiogenesis in the presence of normal interstitial tissue during treatment with cyproterone acetate can also be explained by the antiandrogenic action of this steroid at the level of the germinal epithelium. Since androgen probably reaches the seminiferous tubules in 
higher concentration than in peripheral blood, it is understandable that less antagonism at this target site might be observed with a given dose of antiandrogen than would be the case for seminal vesicles or prostates. Since cyproterone acetate treatment does not result in Leydig cell overstimulation, it might be argued that this antiandrogen is unable to overcome the blood-brain barrier (Whalen \& Edwards, 1969; Whalen, Luttge \& Green, 1969; Edwards, 1970). There is, however, some Leydig cell suppression along with increasing inhibition of spermiogenesis after prolonged treatment and this steroid is also capable of blocking ovulation in rats. In men, cyproterone acetate treatment resulted in severe Leydig cell suppression (Markewitz, Veenema, Fingerhut, Nehme-Haily \& Sommers, 1969) and a marked decrease of plasma testosterone levels (Geller, Vazakas, Fruchtman, Newman, Nakao \& Loh, 1968). Inhibitory central effects of cyproterone acetate can, therefore, be assumed.

Any gonadotrophin-secretion-blocking effect of this compound is presumably associated with its strong progestational side activity (Wiechert \& Neumann, 1965). It may be assumed that the delay in the manifestation of the gonadotrophin-suppressing activity of cyproterone acetate and still later, the return of the Leydig cell structure to normal are due to a balance of inhibitory progestational activity and an intrinsic antiandrogen action on the central negative feedback mechanism which responds to deprivation of testosterone by stimulating gonadotrophin secretion. As yet, there is no direct experimental proof of this hypothesis since highly sensitive and accurate gonadotrophin assay techniques are probably required.

However, judging from the changes in Leydig cell histology, the gonadotrophin-inhibiting potency of cyproterone acetate seems to be of the same order as the presumed stimulating activity. An increasing androgen secretion which finally overcomes any antiandrogenic effect is unlikely to occur as would be the case during prolonged cyproterone treatment. Since the balance of gonadotrophin and androgen secretion is least affected by cyproterone acetate and the site of highest androgen concentration is the testis itself, it should be possible to find a dose of the steroid which, while not interfering with testicular functions over a relatively long period of treatment, still achieves considerable suppression of androgen target organs outside the testis. In the second experiment, a daily dose of $2.5 \mathrm{mg}$ cyproterone acetate/rat was found to be highly effective in accessory sexual gland suppression but had no influence on Leydig cells or spermatogenesis, at least over a period of 6 weeks' treatment.

Provided the findings in rats can be applied to men and taking into account the well-known undesirable side effects of oestrogen therapy, e.g. gynaecomastia or blood circulation disturbances, cyproterone acetate treatment might be preferable to oestrogen administration, particularly in long-term therapy of androgen target organ diseases.

However, although the fertility of the rats in our study was completely abolished with the higher dose and considerably reduced with the lower dose, we have strong reservations against the use of cyproterone acetate as a contraceptive agent for men (Whalen \& Luttge, 1969).

Even if the main antifertility effect of the compound is related to impairment or atrophy of the accessory sexual glands and only partly to an arrest of sperma- 
togenesis, this would be undesirable for normal men since the volume of ejaculate would be likely to be reduced. It also seems possible that the penis might be affected for cyproterone acetate has been reported to cause damage to the penile papillae in rats (Davidson, Bloch, Smith \& Weick, 1970). Moreover, the influence of cyproterone acetate is not only restricted to the male reproductive organs but is of a more generalized nature, including effects on such remote androgen targets as enzyme distribution patterns in liver and kidney, sebaceous glands and other organs (see Neumann et al., 1970).

The main objection to the use of cyproterone acetate in healthy men is its distinct suppressive effect on sex drive which has been proved in a great number of patients (Laschet \& Laschet, 1967a, b; Laschet et al., 1967; Giese et al., 1968; Hoffet, 1968; Ott, 1968; Seebandt, 1968), although animal studies failed to show libido inhibition (Zucker, 1966; Beach \& Westbrook, 1968; Whalen \& Edwards, 1969; Whalen \& Luttge, 1969).

\section{ACKNOWLEDGMENT}

One of the authors (H.S.) is indebted to Dr J. M. Davidson of Stanford University, California, who made helpful suggestions in preparation of the manuscript.

\section{REFERENCES}

BeACH, F. A. \& WestBrooK, W. H. (1968) Morphological and behavioural effects of an 'antiandrogen' in male rats. 7 . Endocr. $42,379$.

BLoch, G. J. \& Davidson, J. M. (1967) Antiandrogen implanted in brain stimulates male reproductive system. Science, N.Y. 155, 593.

Davidson, J. M. \& Bloch, G. J. (1969) Neuroendocrine aspects of male reproduction. Biol. Reprod. 1,67 .

Davidson, J. M., Bloch, G. J., SMith, E. R. \& Weick, R. F. (1970) Comparative responses to androgen of anatomic, behavioral and other parameters. 3rd Int. Congr. Hormonal Steroids, Hamburg 1970. Excerpta med. Int. Congr. Ser. 210, Abst. No. 105.

EDWARDs, D. A. (1970) Effects of cyproterone acetate on aggressive behaviour and the seminal vesicles of male mice. F. Endocr. 46, 477.

Geller, J., Vazakas, G., Fruchtman, B., Newman, H., Nakao, K. \& Loh, A. (1968) The effect of cyproterone acetate on advanced carcinoma of the prostate. Surgery Gynec. Obstet. 127, 749.

Grese, H., Krause, W. F. J. \& Schmidt, H. (1968) Sexualhormone in Beziehung zur Sexualität. Forum der Psychiatrie, 20, 189.

HoFfET, H. (1968) Über die Anwendung des Testosteronblockers Cyproteronazetat (SH 714) bei Sexualdelinquenten und psychiatrischen Anstaltspatienten (vorläufige Mitteilung). Praxis, 57, 221.

HoHLwEG, W. (1956) Über die Bedeutung der Regulation der peripheren Hormondrüsen im Hinblick auf eine praktische Hormontherapie. Dte. GesundhWes. 11, 245.

Junkmann, K. \& Neumann, F. (1964) Zum Wirkungsmechanismus von an Feten antimaskulin wirksamen Gestagenen. Acta endocr., Copenh. Suppl. 90, 139.

LASCHET, U. \& LASCHET, L. (1967a) Die Behandlung der pathologisch gesteigerten und abartigen Sexualität des Mannes mit dem Antiandrogen Cyproteronacetat. 12. Symp. Dtsch. Gesellschaft für Endokrinologie, Würzburg, p. 116. Springer, Berlin.

LASCHET, U. \& LASCHET, L. (1967b) Antiandrogentherapie der pathologisch gesteigerten und abartigen Sexualität des Mannes. Klin. Wschr. 45, 324.

Laschet, U., Laschet, L., Fetzaner, H.-R., Glaesel, H.-U., Mall, G. \& NaAB, M. (1967) Results in the treatment of hyper- or abnormal sexuality of men with antiandrogens. Acta endocr., Copenh. Suppl. 119, 54 .

Markewitz, M., Veenema, R. J., Fingerhut, B., Nehme-Haily, D. \& Sommers, S. C. (1969) Cyproterone acetate (SH 714) effect on histology and nucleic acid synthesis in the testes of patients with prostatic carcinoma. Investve Urol. 6, 638. 
Mretkiewski, K. \& LuKaszyK, A. (1969) The response of the rat testis to prolonged administration of an androgen antagonist (cyproterone). Acta endocr., Copenh. 60, 561.

MiETKIEWsKi, K., Malendowicz, L. \& LuKaszyK, A. (1969) Cytological and cytochemical comparative study on the effect of cyproterone (anti-androgen) and gonadectomy on the gonadotrophic cells of the hypophysis in male rats. Acta endocr., Copenh. 61, 293.

Neumann, F. (1966) Auftreten von Kastrationszellen im Hypophysenvorderlappen männlicher Ratten nach Behandlung mit einem Antiandrogen. Acta endocr., Copenh. 53, 53.

Neumann, F., Elger, W., Steinbeck, H. \& Von Berswordt-Wallrabe, R. (1968) Antiandrogene. 13. Symp. Dtsch. Gesellschaft für Endocrinologie, Würzburg 1969. In: Das Testoterun-Die Struma, Ed. E. Klein. Springer, Berlin.

Neumann, F., Elger, W. \& Von Berswordt-Wallrabe, R. (1966) Aufhebung der Testosteronpropionat-induzierten Unterdrückung des Vaginal-Zyklus und der Ovulation durch ein antiandrogen wirksames Steroid an Ratten. Acta endocr., Copenh. 52, 63.

Neumans, F., Elger, W., Von Berswordt-Wallrage, R. \& Kramer, M. (1966) Beeinflussung der Regelmechanismen des Hypophysenzwischenhirnsystems von Ratten durch einen TestosteronAntagonisten ,Cyproteron (1, $2 \alpha$-Methylen-6-chlor- $\Delta^{4,6}$-pregnadien-17 $\alpha$-ol-3,20-dion). NaunynSchmiedebergs Arch. exp. Path. Pharmak. 255, 221.

Neumann, F., Steinbeck, H., Elger, W. \& Von Berswordt-Wallrabe, R. (1968) Hoden-Morphologie und Funktion unter der Einwirkung von PMS und HCG bei gleichzeitiger AntiandrogenBehandlung. Acta endocr., Copenh. 57, 639.

Neumann, F., Von Berswordt-Wallrabe, R., Elger, W., Steinbeck, H., Hahn, J. D. \& Kramer, M. (1970) Aspects of androgen-dependent events as studied by antiandrogens. Recent Prog. Horm. Res. 26, 337.

OTт, F. (1968) Hypersexualität, Antiandrogene und Hodenfunktion. Praxis, 57, 218.

SeEband, G. (1968) Gedanken und U'berlegungen zur Behandlung sexualtriebabartiger Psychopathen mit Antiandrogenen. Off. GesundhWes. 30, 66.

Steinbeck, H., Elger, W. \& Neumann, F. (1967) Sexual activity of male rats under the influence of estradiol and antiandrogens and recurrence of libido after cessation of treatment. Acta endocr., Copenh. Suppl. 119, 63 (Abstr. No. 47).

Voigt, K. D., Apostolakis, M. \& Klosterhalfen, H. (1968) The influence of cyproterone treatment on the excretion of steroids in male patients. In: Testosterone, p. 152. Ed: J. Tamm. Georg Thieme, Stuttgart.

Von Berswordt-Wallrabe, R. \& Neumann, F. (1967) Influence of a testosterone antagonist (cyproterone) on pituitary and serum FsH-content in juvenile male rats. Neuroendocrinology, 2, 107.

Von Berswordt-Wallrabe, R. \& NeumanN, F. (1968) Influence of a testosterone antagonist (cyproterone) on pituitary and serum ICSH-content in juvenile male rats. Neuroendocrinology, 3, 332.

Whalen, R. E. \& EdWARDs, D. A. (1969) Effects of the anti-androgen cyproterone acetate on mating behaviour and seminal vesicle tissue in male rats. Endocrinology, 84, 155.

Whalen, R. E. \& LuttGe, W. G. (1969) Contraceptive properties of the anti-androgen cyproterone acetate. Nature, Lond. 223, 633.

Whalen, R. E., Lutrge, W. G. \& Green, R. (1969) Effects of the antiandrogen cyproterone acetate on the uptake of $1,2-{ }^{3} \mathrm{H}$-testosterone in neural and peripheral tissues of the castrate male rat. Endocrinology, 84, 217.

Wiechert, R. \& NeumanN, F. (1965) Gestagene Wirksamkeit von 1-Methyl- und 1,2 $\alpha$-MethylenSteroiden. Arzneimittel-Forsch. 15, 244.

ZUCKer, I. (1966) Effects of an anti-androgen on the mating behaviour of male guinea-pigs and rats. $\mathcal{F}$. Endocr. 35, 209. 